\title{
MARTHA BIBESCU, A „FLOWER” AMONG ROMANIAN FRANCOPHONE WRITERS
}

\author{
MARTHA BIBESCU, UNE «FLEUR »PARMI \\ LES ÉCRIVAINS ROUMAINS FRANCOPHONES
}

\author{
Onorina BOTEZAT 1 \\ https://doi.org/10.52744/9786062613242.06
}

\begin{abstract}
Princess Martha Bibescu plays an important role in Romanian Francophone culture. A Romanian aristocrat, she conducted a successful literary career writing both nonfiction and novels during the first half of the twentieth century. She was also a laureate of the French Academy and a member of the Royal Belgian Academy of French Language and Literature. Known for her charming personality, intelligence and beauty, she proudly shared her dual cultural identity: French and Romanian. During the first part of her life, Princess Bibescu was admired for her wealth and grace, and her relations with the last kings of Europe as well as with an impressive number of chiefs of state. In the second part of her life, a period marked by hardship and the loss of a huge fortune, Martha Bibescu travelled, wrote, experienced personally the disruptive events in European history, assumed with dignity her social role of confident and supporting relative, turned writing into a livelihood, overrode personal loss and cherished the only single passion in her life: writing.
\end{abstract}

Keywords: Martha Bibescu; Romanian Francophone Culture; Anemone; Travel

Résumé : La Princesse Martha Bibescu joue un rôle important dans la culture francophone roumaine. Aristocrate roumaine, elle a eu une brillante carrière littéraire dans la première moitié du XXe siècle. Lauréate de l'Académie française et membre de l'Académie royale belge de langue et littérature françaises, elle était connue pour sa charmante personnalité, son intelligence, sa beauté et sa fierté de posséder une double identité culturelle : française et roumaine. Pendant la première partie de sa vie, la Princesse Bibescu a été admirée pour sa richesse et sa grâce, ainsi que pour les relations qu'elle entretenait avec les derniers rois d'Europe et un nombre impressionnant de chefs d'État. Dans la deuxième partie de sa vie, période marquée par la misère et la perte d'une énorme fortune, Martha Bibescu a voyagé, écrit et affronté les événements perturbateurs de l'histoire européenne ; elle a assumé avec dignité son rôle social de soutien de ses proches, surmonté les pertes personnelles et chéri la seule passion de sa vie : l'écriture.

Mots-clés: Martha Bibescu; Culture francophone roumaine; Anémone; Voyage

\footnotetext{
${ }^{1}$ Associate Professor PhD., Dimitrie Cantemir Christian University of Bucharest, Faculty of Foreign Languages and Literatures, Onorina.botezat@ucdc.ro
} 


\section{Early years of Martha Lahovari}

Martha $^{2}$ Lucia Lahovari, the future Princess Bibesco, 3 is known to the Romanian public as an author who wrote in French and to European readers as a French writer of Romanian origin. Educated in the French tradition, studying English and German as well, she began her literary career writing about her travels and went on to publish a great number of novels, essays, memoirs, travel stories, and correspondence. She maintained personal and diplomatic relationships with the prominent men and women of her time.

Proud of her parents' families and the royal family into which she married, Martha embraced her Romanians roots and Romanian history in her writings, most of them written in French. Her father's family, the Lahovaris, represented the rich and cultivated bourgeois which appeared in Romania in the period 1867-1940 and which played a prominent role in politics. Her father, Ion, was himself actively involved in politics as Chairman of the Senate, Minister of External Affairs, and Romanian Ambassador to France. He had married Smaranda (Emma) Mavrocordat in 1880, the granddaughter of the Romanian voivode Constantin Mavrocordat, a famous family of Phanariots long established in Moldova.

Born on January 28, 1886,4 Martha Lahovari grew up in the manor of Baloteşti, near Bucharest, and spent most of her youth in France. She was a bright and intelligent child, fond of religion, literature and history, and educated through French, German and English. It is only at the age of eleven that she began to learn Romanian.

Martha Lahovari was raised mainly by men. Like her fictional character Catherine, whom the author described in Catherine-Paris, at

2 A portrait of Martha Bibescu - "(Re)constructing Identity Roots in Martha Bibesco's Writing" - was published in Ramona Mihăilă, Efstratia Oktapoda, Nancy Honicker (eds.). Gender Studies in the Age of Globalization Bucharest, June 2-3 2011, Vol 1, New York: Addleton Academic Publishers, 258-265 and a short version of it was provided for the database of the European project "Women Writers in History: Toward a New Understanding of European Literary Culture."

3 Also known as Lucile Decaux, Martha Bibescu, Marthe Bibesco, Princesse Bibesco, Marthe Lucie Bibesco, Princess Marthe Bibesco, Marthe Lucie Lahovary Bibesco. In this paper, we use the Romanian orthography, Martha Bibescu; where quotations appear in this essay, we use the author's name as placed on the cover of the book from which the quotation is taken.

4 There are sources that indicate 1888 or even 1889 as year of her birth, mainly because Princess Bibesco often misrepresented her age for various reasons. In an interview, in 1936, Lahovari referred to her first book as written at the age of eighteen as well. Other misleading information may be traced from the novel Catherine-Paris, where the main character is born January 28, 1889 . 
the age of seven she "passed from women's domination to men's command." (Bibescu 2013, 23) Her father, who showed love and devotion, oversaw her intellectual formation, along with her uncle, Jacques Lahovari, hero of the Battle of Plevna, and her maternal grandfather, Alexandre Mavrocordat, - all admired her precocious mental development and her personality. (Ferent 2010, 3) We see a parallel in Catherine's education, which was shared by two men: "Catherine's intelligence is now divided between two magistrates: her uncle, classically rooted, and Mr. Beau, the romantic." (Bibescu 2013, 34) Emma Mavrocordat, Martha's mother, favored her only son George, whose early death at the age of eight left her crestfallen mother; she "obstinately remained in mourning all her life." (Bibescu 2014, 11)

Although her mother, "always laying in the dark room" (Bibescu 2014, 16) withheld her affection 5 towards her daughters (Bibescu 2014, 20), who could see her but once a day, Martha would receive some maternal affection later from Queen Marie and Princess Georges Bibesco. At age of twelve, she was placed by her parents in the care of the circle surrounding the future Romanian royal family, in particular Princess Marie, the future Queen of Romania, who nicknamed Martha "Pony" and was impressed by her encyclopedic knowledge and her exceptional memory, and who enjoyed her company. Young and beautiful, Martha was asked by the then Romanian Queen Elisabeth (known to the literary public as Carmen Sylva) to pose for some paintings in the church of Curtea de Arges.. ${ }^{6}$ After a series of holidays spent with the royal family in Constanța she developed a friendship with the young future king, Prince Ferdinand.

\section{Marriage, travels and first writings}

At only fourteen she was betrothed to George Valentin Bibesco and moved to her inlaws' Posada Castle. As Martha recalled herself in the introduction to A Daughter of Napoleon. Memoirs of Emilie de Pellapra Princess de Chimay:

I was fifteen years of age when, as her future daughter-in-law, I was placed in the care of my aunt. Princess George Bibesco (Valentine de Riquet, Comtesse de Caraman-Chimay, Princesse Bibesco, born at Menars, February, 1839, died at Bucharest, August 25th, 1914) and I, fortunately, understood at

5 The lack of maternal affection haunted Martha Lahovari all her life. Later, when she described Catherine, her fictional character in Catherine-Paris, the author said she was raised without parents, underlying the fact that she only ever saw her mother in her dreams in Paris.

${ }^{6}$ Curtea de Arges is a monastery, of great architectural value, transformed by Carol I of Romania into the necropolis of the royal family. 
once that her rod was really a magic wand, that no fate could have suited me better, for if the fairies were not at my baptism I was sure of one at my wedding, since my mother-in-law was a fairy herself. (Pellapra 1922, 3)

Reading voraciously and especially fond of history, she studied the life of Napoleon, being "only a schoolgirl, with a governess to rule over me, seeing my parents-in-law on Thursdays and Sundays, and receiving visits from my betrothed, which were a great interruption to my lessons." (Pellapra 1922, 4) She would describe her hurried betrothal and unhappy marriage later, in the novel Catherine-Paris, but the wedding basket, with family jewelry, and Napoleon's memoirs (Pellapra 1922, 7) she relates in the introduction to A Daughter of Napoleon.

When married to Prince George III Valentin Bibescu, descendant of one of the country's aristocratic families, Martha was seduced by the idea of an alliance with a European family that had both noble roots and prominence in the social life of Paris7. As much as Martha cherished her family-in-law's roots, Mircea Eliade found that "she was almost frightened at the idea of being a Bibesco, and at knowing that so much blue blood flowed in her veins." (Eliade 1989, 252) But the marriage itself was a great disappointment to Martha, as George Bibescu did not show the same interest in art as his famous cousin Anna de Noailles, preferring love - with other women - and sport. While drawing the story of Emilie and her mother, in the introduction to Une fille de Napoléon [A Daughter of Napoleon], she made an observation that seemed to closely relate to her own intimate: "All women die for the first time with their youth." (Pellapra 1922, 18)

Disappointed to be treated as a mere laurel for her husband, and after having discovered that the "marriage was unhappiness, not an occupation," (Bibescu 2013, 82) Martha often found herself alone in the Bibescu mansion such that she viewed herself as trapped in the "shut-in country" (Bibescu 1925) of Posada. This was the house where she gave birth to a daughter, Valentine, whose birth had nearly cost Martha her life and who embodied her unhappy marriage; the outcome of this situation was that she refused to focus on her new child.

As noted, George Valentin Bibescu was a sportsman, the first Romanian automobilist (among the first in Europe) and a great pilot, indeed reaching the brevet rank of pilot-aviator at the Louis Bleriot flying school so, too, was he the president of the Fédération Aéronautique Internationale (The World Air Sports Federation). The son of George

7 While delivering the inauguration Speech at the Académie Royale de Langues et Littératures Françaises de Belgique in April 1955, she expressed her admiration and paid tribute to her family-in-law. See Daubigny (2012). 
Bibescu and Valentine de Riquet, the young man inherited from his mother the recklessness and the Bonapartist spirit of adventure and from his father the sense of his own noble past and a passion for history. Having gained notice for his car races and rallies, and co-founding the Romanian automobile club, the King sent him in 1905 on an official mission - by car - to Persia, accompanied by Martha, now the Princess Bibesco.

This journey was the start of what would be a series of wanderings around the world 8 and its result was Martha's first book, Les Huit Paradis [The Eight Paradises], which appeared in 1908 and was awarded by the French Academy. Her work, Berlin Journal ' 38 , was also the outcome of a trip made to accompany her husband, this time to an International Congress of the Aeronautic Federation in Berlin, an occasion that she used to describe Germany and its people (Dascălu 2011) in a diary that she did not initially mean to publish. The Journal depicted the period of 21-27 June 1938 in Berlin, with a sentimental reunion with her past - a visit to Potsdam, the official residence of Wilhelm III and an official dinner offered by the Reich, where she met the family of Hermann Goring.

The Romanian translation of The Eight Paradises made by Tudor Nicolaescu contains as its preface an unanswered letter written in Romanian and French, signed "Marthe, Princess Bibesco" at Constantinople (as she would refer to Istanbul) in 1944, addressed to her translator, a young man who had died in 1943, without seeing his translation published. The letter is signed in this city where the first journey, narrated by the young Bibescu, had come to an end, a promise to this young man who had wanted to translate The Eight Paradises into Romanian. The letter is of great interest as it tells us how Maurice Barrès, the author of Leurs figures (1902), convinced Martha Bibescu to publish her memoirs of the trip. In a conversation about Martha's Persian trip, Barrès asked her a lot of questions regarding the trip and when she planned to publish her account. Her remarks, whether made on purpose or not in 1944, when she was recalling the story in her letter, disclosed a

\footnotetext{
${ }^{8}$ Queen Maria, in her memoirs The story of my life wrote: "Character is destiny. Marthe meant to advance and succeed, and this she did. She attracted into her life those things of which she dreamed. She became acquainted with those whose names are foremost in our striving, changing world of to-day. Little by little she grouped people of talent and interest around her. Her keen mind is open to every social advantage, she entertains royalty, diplomats, politicians, artists, writers, scientists and aristocrats. She travels in many lands and her hosts are always amongst the most select and renowned, and as when she was a little girl and I called her "Pony," her ears and her eyes are wide open, she absorbs and never forgets anything she sees and hears. And Marthe has become a much-talked-of and appreciated writer, a writer admired by the most critical critics. Her French is faultless, her style delicately perfect; the pictures she evokes are rich and full of poetry, her books are wise and deeply studied and every sentence is polished like a precious stone.” In Marie, Queen of Romania (1934, 444-445).
} 
gendered approach towards travel literature, underscoring her concern as to how could she dare publish a book about Persia after Loti's Vers Ispahan." The answer of Barrès is revealing: "The book written by Loti is the book of a man of age; yours shall be the book of a young woman of 18 years old. I can't see any relation." (Bibescu 1946, 14) So were put to rest her concerns of being overshadowed by Loti's earlier work.

The book is conceived in eight chapters, each of them dedicated to one city: Rescht, Teheran, the holy city Qum, Kashan, Ispahan, Lenkoran, Trabzun, and Constantinople. If Loti found Teheran to be too modernized,9 Martha Bibescu "knows that Teheran is almost modern, with barely sprinkled streets and that its tiles are from an unhappy era." (Bibescu 1946, 71) What the princess loved about the city were its gardens and roses, being known for her love of flowers, a subject on which she published a book, Flowers: tulips, hyacinths, narcissi, accompanied by the drawings of Arlette Davids at Hyperion Press, Paris, in 1940. These Asian memoirs open with a phrase chosen from the Persian poet Saadi: "I am nothing but a priceless clay, but for some time, I lived with the rose" (Bibescu 1946, 23) and an introduction by the author comparing the eight visited Islamic cities to gardens. Wandering through Rescht, the princess discovered what she believed to be the secret of Persian gardens: they blossomed in rows, with irises, white and red lilies and yellow tulips that the author described as smelling like autumn pears.

Claude Anet, in Les roses d'Ispahan, La Perse en automobile à travers la Russie et le Caucase, described Martha Bibescu's trip with her husband to Persia from a masculine perspective, depicting the roads and the cars, a very technical and timed schedule, short and numerical data about people and places, the difficulties encountered by the women ${ }^{10}$ that

\footnotetext{
9 See Loti (1904): “Avec défiance et ennui, nous arriverons demain à Téhéran, ville sans doute trop modernisée qui à peine nous semblera persane, après les vieilles capitales du temps passé, Ispahan et Chiraz." ("With distrust and trouble, we will arrive tomorrow in Tehran, a city that is without doubt too modernized that it barely seems Persian, after the old capitals of the past, Ispahan and Shiraz) (our translation in English).

10 Anet (1906, XIII-IX). "Nous emmenions deux jeunes femmes avec nous, ou plutôt nous emmenaient-elles, tant étaient vifs leur enthousiasme, leur gaîté, leur courage, leur volonté d'arriver quand même. Ces jeunes femmes étaient habituées à la paresse, au confort, au luxe. Elles ont connu les nuits sans sommeil, les nourritures insuffisantes, les gîtes malpropres, le froid de l'aube, le vent dans les montagnes et la chaleur qui monte du désert à midi si forte qu'on reste engourdi et qu'on voudrait mourir..." ("We took with us two young women, or rather we were taken by them, so keen was their enthusiasm, cheerfulness, courage, and willingness to arrive at last. These young women were accustomed to laziness, comfort, and luxury. They have experienced sleepless nights, poor food, dirty houses, cold dawns, the wind in the mountains and the rising heat of the midday desert that is so strong that one remains numb and would like to die...") (our translation in English).
} 
accompanied them through the journey, and the delighted attitude of people towards European visitors. Setting the scene and describing the purposes of the journey, the author confirms the princess's love of flowers, mentioning that she wondered where she might find them in the desert. (Anet 1906, XI-XII)

\section{The Anemone, flower of wind}

Martha's bond with nature, flowers and herbs is revealed in every piece of her writing and may be considered as the pillar that supports her personal philosophy. She associates flowers with a great range of feelings: the withheld love of her mother, ${ }^{11}$ the unhappiness of a young woman after her first unpleasant experience of what should have been a night of love with her husband,12 the thoughtfulness of a young lover who offers her lilies. (Bibescu 2013, 10) She is so profoundly fond of flowers that they seem to heal her pain even when she suffers enormously, as it was when her father died and she compared the event to the cutting off a flower from its roots (Bibescu 2013, 83), or when she lost her green parrot but nonetheless did not jump through the window to save it, so as not to destroy the beautiful blossomed camellias. (Bibescu 2014, 37)

She compares flowers to friends: "The flowers are for me as my friends' eyes. They spy on me, give me signs and I exchange with them long accomplice-like glances." (Bibescu 2014, 21) She confesses in her book Isvor that "When a man starts building a house, he begins with planting a willow, in other words by making a miracle: he puts a stick in the ground, which afterwards becomes a wonderful tree." (Bibescu 2000, 20) The personal coat of arms that Martha adopted, during a trip to Jerusalem, could be nothing else but a flower - the anemone, flower of wind, which corresponds so well with her wandering soul and served through years as healing for the deceptions of her husband. In her memoirs, the Queen Maria of Romania underlined the fact that "the flowers cultivated by her [Marthe Bibescu] were wonderful and I loved walking along with her through her domain, admiring her unequalled taste." (Marie, Queen of Romania, 63-64) Martha herself colorfully described her gardens in Mogoşoaia in "My Roumania”:

\footnotetext{
${ }^{11}$ See Bibescu (2014, 20): "My attention, that my mother never notices, is free to wander wherever it wants. My instinct lurks here and there, sensing the time and sniffing fields, my eyes are everywhere, and I discover at the hollow wayside the white hoarfrost on the grass and rocks, traces of winter fairy; on the other side of the road, one, two, three primrose flowers, along with some marguerites, the first to open, tiny, that follow me furtively." (o.t.)

${ }_{12}$ See Bibescu $(2013,80)$ : "In the lamplight of the sleeper, Catherine found herself alone with the flowers as in a fresh grave. The bouquets jumped along, swinging the corollas." (o.t.)
} 
Palade Primovara, Palace of Springtime, is a name everlastingly deserved by Mogosoëa, in its setting of weeping willows, the first trees to show green, and of irises, blooming in legions as they must always have bloomed, since one finds them everywhere, conventionalized in the carvings of ancient stone balconies. In one night, in this magical climate, great armies of irises unfurl their banners to the breezes; all earth and water turn purple every spring at the feast of Saint George. In the garden at Mogosoëa, countless numbers of the blue and violet standards cluster on each side of the steps - the Venetian scala which leads from the lower flower-beds to the terrace above. In only a few days, alas, the ruthless sun strikes these opalescent tents and lowers the lovely lances, and the charming army is put to rout. It is then replaced by scarlet ranks of Oriental poppies and by the white chalices of the water-lilies which have lain hidden in the languorous waters of the Colentina, needing only the warmth of June to draw them out like the magically multiplied cup of the King of Thulé. (Bibesco 1925)

\section{The literary consecration}

Though her life was marked by loss (the suicide of her close confidant and cousin Emmanuel Bibesco in 1917, the death of her sister Margaret in 1918 and of her mother in 1920), and an unhappy marriage, her passion for letters had never left her and she dedicated herself to writing. Written in French, 13 Martha signed her books "Princess Bibesco". After the success of her first book of travel memoirs, filled with an air of exoticism and legend, Martha put on paper her passion for history, embodied in the publication of a work on Alexander the Great, a poetic blend of history and legend, entitled Alexandre l'Asiatique ou L'Histoire du plus grand bonheur possible [Asian Alexander], published in 1913; it was followed by numerous works of historical inspiration: Une fille de Napoléon [A daughter of Napoleon] in 1921, republished as Une fille inconnue de Napoléon [An unknown girl of Napoleon]; and later, Marie Waleska, in 1936. The books offer her personal interpretation and fictional account of the life of Napoleon. Her boundless enthusiasm for the Emperor's life caused her difficult debates with her uncle:

To put the finishing touch to his ascendancy over me, I was at last forced to defend him. I had great love, even admiration, for an uncle of mine, whose

13 In an interview to the Ilustrațiunea română (Romanian illustration), published January, $5^{\text {th }}, 1936$ and signed S. C., Princess Bibescu said: "I write in French because my mother, born Mavrocordat, married Lahovary, and following the loss of a child left her mansion in Romania, settling in Paris, when I was only five years old. This explains why the language in which I express my thoughts is French. I am convinced that this can only bring benefits to a writer of Romanian origin. Writing in a universal language, one may be translated and read throughout the world, thus facilitating knowledge of the autochthonous spirit by those who do not know your language. And I think we all aspire to universality ...” (o.t.) S.C. 1936. "O oră cu Prințesa Martha Bibescu” (“An hour with Princess Bibesco”), Ilustrațiunea română (Romanian illustration), 2(An VIII): 15. 
generous nature had thrown him into a kind of humanitarian idealism. One day he said to test me: 'Who is the greater, Pasteur or Napoleon? Answer quickly now!' His fingers closed sharply on my arm, and his eyes held mine. I had to choose between a benefactor of the race and one whom he wished me to consider as a slaughterer of men. 'Speak up; which was the greater?' With tears in my eyes 1 felt that 1 was lowering myself in the estimation of one whose good opinion 1 highly valued, but I stuck to my colors. 'Napoleon,' I answered, as distinctly as I could.

From that day I was morally disinherited by my uncle, but I held firm. Heated discussions often took place, in which it was clearly proved that even from the military and political point of view Napoleon was criminal, since he left a diminished France. I replied that he had gained for her the illimitable frontiers of the soul, to which my uncle responded conclusively: 'Tertullian has defined man as a glorified animal, a description applicable perhaps to women or even to little girls.' I knew that I was one of these animals, and that is why my mother-in-law made me so happy when she told me of the Emperor some years later. I shall always be grateful to her for this imaginative delight. (Pellapra 1922, 6-7)

In the same framework appears the cycle of historical novels signed under the name Lucile Decaux, of which the most famous remains Katia, le démon bleu du tsar Alexandre [Katia, the blue demon of Tsar Alexander] (Botezat 2013), adapted for film in 1938.

Literary recognition came with the publication in 1923 in Paris of Isvor, le pays des saules [Isvor, Land of willows], in London in 1924, and in Bucharest in 1938, a work hailed by the press, which called it an amazing peasant fiction and autobiographical confession. She confessed in Isvor, Land of Willows that out of a lack of activity she began to write and to travel.

Isvor m'avait été inspiré par la vie quotidienne des villages, par les rites traditionnels observés dans leur existence millénaire, par les paysans de ce domaine forestier de la montagne où j'étais venue vivre, pour toujours croyais-je alors, aussitôt après mon mariage. Ce livre était fait de notes que j'avais prises au jour le jour; il ne contenait pas une seule histoire qui ne fût vraie, un seul épisode inventé. Tout ce qui s'y trouvait d'expérience m'était réellement arrivé; je m'étais profondément attachée à ces gens, à cette nature où ils vivaient si singulièrement isolés dans le temps que je l'étais moi-même dans l'espace. (Bibesco 1955, 72)

In 1924, the novel Le Perroquet Vert [The Green Parrot], she felt and exhibited a new literary creativeness and freedom, in which fiction was used both to evoke and conceal the memories of her unhappy childhood. „Je me sens incapable d'écrire quelque chose que je n'ai pas vécu ou tout au moins faut-il que j'aie participé à ce que je conte, si peu que ce soit. J'ai besoin d'un fait très précis pour déclencher le mécanisme imaginatif." (Bibesco 1930, 61) 
In the same key of autobiographical echoes, Catherine-Paris (1927) portrayed Parisian high society at the end of the European belle époque, with a vivid description of Europe before World War I. It was the novel that enjoyed the greatest success with the public and her second novel to be adapted for film, this time in the U.S. in 1933. Catherine-Paris is the name of a nonconformist princess with Romanian origins, who lives modestly in Paris, reads extensively, and prefers the company of two old teachers. Far from being a fashionable lady, but rather a studious teenager with republican convictions, Catherine-Paris marries the scion of an old Polish princely family, Adam Leopolski, and enters into a life dominated by of protocol required by her new rank. Caught in a whirlwind of disappointments and transient pleasures, the fragile and luminous princess very soon felt like a foreigner to her family. Everyone likes and admires her intelligence and beauty, but apart from social convenience and traditional gossips, she feels abandoned and treated with a cold indifference. As in The Green Parrot, where her sole devotion was forever promised to the green Parrot that she adored, in Catherine-Paris it is the city of Paris, a character in itself, that she trusts and loves. Once again, her true love and deep feelings are not related to human beings, which, as she said, betray and never offer comfort. Based on reigning social rules, Catherine-Paris will not criticize the hobbies and love affairs of her husband, accepting them instead as the price, and custom, of her new social position. To overcome the oddities and continuous separations of such a family life, Catherine-Paris returns to Paris to renew her wardrobe for the new trends of the season, yet another reason for which she praises the legendary city.

In 1928 she published Au bal avec Marcel Proust [At the ball with Marcel Proust], a book of her personal correspondence and that of her cousins Antoine and Emmanuel Bibescu with the French writer. This work is the first in a series of publications where the princess evoked the memory of Proust, as in Le Voyageur voilé, Marcel Proust, lettres au duc de Guiche et documents inédits (1947) and La duchesse de Guermantes, Laure de Sade, Comtesse de Chevigné, avec des pages inédites de Marcel Proust (1951), while the Le confesseur et les poètes (1970) outlines the portrait of Proust among a gallery of famous figures, including Jean Cocteau, Robert de Montesquiou, Paul Valery, and Maurice Baring.

During the twentieth century Princess Bibesco travelled and met numerous international figures, receiving a warm welcome at the royal court in Romania, then from the Crown Prince of Germany, the latter friendship that diminished her in the eyes of the Romanian crown, despite her sustained activity running a hospital in Bucharest during World War I. When she returned to Romania, she dedicated almost twenty years of 
her life to restore Mogoşoaia Castle, but after 1945 she moved to Paris and never came back. Throughout her writings, whether fiction, historical, or correspondence, she always found the opportunity to refer to Romanian history (Albu-Comănescu 2015, 91-101), pointing to great examples of rulers and acting as a bridge to the West for the long traditions of the country. In 1955 she was elected to the Royal Academy of French Language and Literature of Belgium.

Martha Bibesco was part of the social and literary elite, and was recognized not only in the Parisian salons but appreciated by many personalities in many countries through her countless trips and due to her husband's prominence during the inter-war period. She met U.S. President Franklin Roosevelt, British Prime Minister Ramsay MacDonald (who signed the preface of her book Le destin de Lord Thomson of Cardington), Winston Churchill, Aristide Briand, Paul Claudel, Maurice Paleologus, the famous aviator Louis Blériot, Charlie Chaplin, Cella Delavrancea, Dinu Lipatti, the Romanian archaeologist and historian Vasile Parvan (with whom she maintained a long correspondence), and numerous writers of her time. Princess Martha Bibesco died at the age of eighty-seven on 28 November 1973.

\section{References}

Albu-Comănescu, Radu. (2015). «Marthe Bibesco, diplomate culturel: une grande européenne», Synergies Roumanie, 10: 91-101.

Anet, Claude. (1906). Les roses d'Ispahan. La Perse en automobile à travers la Russie et le Caucase. Paris: Librairie Felix Juven, XIII-IX.

Bibesco, Martha. (1925). "My Roumania”, Vogue Magazine, Londres, 15 juin 1925. http://www.tkinter.smig. net/romania/Bibesco/index.htm.

Bibescu, Martha. (1946). Cele opt raiuri. Translated by Tudor Nicolaescu, with a letter written by Marthe, Princesse Bibesco in Romanian and French, January 28, 1944, Constantinople. Bucureşti: Fundația Regală pentru literatură şi artă.

Bibescu, Martha. (2000). Izvor. Ţara sălciilor. Translated by Anca Maria Christodorescu. Bucharest: Compania.

Bibescu, Martha. (2013). Catherine-Paris. Translated from French and notes Magda Răduță. Iaşi: Polirom.

Bibescu, Martha. (2014). Papagalul verde [The green parrot]. Bucureşti: Polirom. The Romanian translation from French Edition Editions Grasset \& Fasquelle, 1924, by Constantin Popescu.

Dascălu, Bogdan-Mihai. (2011). Germanitatea şi Literele Române [Germans and Romanian Literature]. București: Ideea Europeană, ebook.

Daubigny, Fanny. (2012). "Étude du discours de remerciement de Marthe Bibesco prononcé devant l'Académie Royale de Langues et Littératures Françaises de Belgique». Thélème. Revista Complutense de Estudios Franceses, Vol. 27: 133145 .

Eliade, Mircea. (1989). Journal III. 1970-1978. Translated from French by Teresa 
Lavender Fagan. Chicago and London: The University Chicago Press.

Ferent, Simona-Veronica. (2010). Le JE et l'AUTRE, ou comment l'altérité répond a l'identité. Questionnements chez Marthe Bibesco Isvor, le pays des saules et Le Perroquet Vert, [These pour obtenir le grade de Docteur de l'Université de Limoges].

Frosin Constantin. (2009). «Marthe Bibesco, une princesse de la poésie». Parcours féminins. L’intellectuelle. Coordonator Pierre Morel. Chişinău: Foxtrot, 79-85.

Loti, Pierre. (1904). Vers Ispahan. Bibebook.

Marie, Queen of Romania. (1934). The story of my life. New York: Charles Scribner's Sons.

Obreja, Cristina-Maria. (2010). «Le voyage comme quête de soi dans l'œuvre de la Princesse Marthe Bibesco». DOCT-US Journal Vol 2(2): 71-77.

Ornea, Zigu. (2001). «Martha Bibescu în 1915». Literary Romania (România literară), 30: 9 .

Pellapra, Emilie de. (1922). A daughter of Napoleon. Memoirs of Emilie de Pellapra Comptesse de Brigode Princess de Chimay. With an Introduction by Martha Bibesco, Preface by Frederic Masson, Translated by Catherine Miller. New York: Charles Scribner's Sons.

Princesse Bibesco, (1930). «Pourquoij’écris? De peur d'oublier la vie.» Ainsi parla... La Princesse Bibesco. Paroles recueillies par Georges R.-Manue. Paris: Éditions Nilsson.

S.C. (1936). "O oră cu Prințesa Martha Bibescu” [An hour with Princess Bibesco], Ilustrațiunea română [Romanian illustration]. 2(An VIII): 15. 